\title{
Engagement and Prosumer Commodification: How Does the Web Make Profit?
}

\author{
Muria Endah Sokowati \\ Department of Communication \\ Universitas Muhammadiyah Yogyakarta \\ Yogyakarta, Indonesia \\ muriaendah@umy.ac.id
}

\begin{abstract}
This article describes the practice of prosumer commodification, which works on the process of Mojok.co's production, distribution, and consumption. Mojok.co is an online media containing articles in relaxing, sarcastic, satirical, and fun. This unique format brings the image of Mojok.co as alternative media. The community engagement as a business strategy run by Mojok.co to maintain its performance in the online media industry also strengthens this image. Community engagement is the strategy involving the viewer in the process of production, distribution and consumption. Understanding the implementation of this strategy shows the works of the practice of prosumer commodification.
\end{abstract}

Keywords-engagement, prosumer commodification, online media, business strategy

\section{INTRODUCTION}

I prepared to write this article based on my previous research on alternative media. At that time, I was interested in understanding the emergence of various communication platforms driven by the rapid development of communication and information technology. The new media has multiple characteristics, which is different from the mainstream media format we usually see in conventional media. So, I was eager to know the pattern of production, distribution and consumption of the new media.

Then, I chose Mojok.co as the locus of my research. It is an online media site with a unique characteristic, which differentiate this site to others. I tried to learn how the process of production, distribution and consumption of this site as alternative media, since Mojok.co has succeeded to maintain its existence in the online media industry.

Mojok.co's primary strategy is the commitment to get community engagement. The media needs to make a relationship with its viewers. It is essential to get involved the viewers in the process of producing and distributing contents. Web 4.0 technology allows the process of engagement. Web 4.0 technology has blurred the roles of media producers and consumers. The users of this technology have no definite position whether he/she is the content producer or consumer. $\mathrm{He} / \mathrm{she}$ can be both the producer and the consumer.

On the one hand, the involvement of viewers in the process of production and distribution is a progressive step. As we know, the conventional media treats the audience to be the passive consumer, since they can do nothing but accept the content. The new media technology has transformed the concept of the audience with their passive consumption to be more empowered. The community engagement becomes the example of audience empowerment. In the new media, there are more activities for the audience, starting from giving responses, even becoming a content provider. The word "audience" is no longer match to this mode of communication. The "user" is better used to describe the double roles of producers and consumers as well. In this article, I will use the word "viewers", as a more common term to describe the users of Mojok.co.

But on the other hand, I see the strategy of community engagement as the practice of commodification. The viewers have active roles in the phase of production and distribution. In the distribution phase, they are involved in disseminating the contents. The viewers can share the Mojok.co's articles in their social media accounts. The more articles shared, the more viewers will visit the web. In the production phase, the viewers can have the opportunity to be the content provider. Mojok.co gives the payment for the viewers' articles publications.

I see in the distribution phase, Mojok.co has taken advantage of the viewers to run the web's performance. The viewers have become the unpaid labours that "work" for Mojok.co. It is the practice of commodification, and this article will describe the practice.

\section{DISCUSSION}

\section{A. Mojok.co: From Alternative Media To The Integration}

Mojok.co is an online media, first published on August 28,2014 . This media is impressive because it has unique contents. The unique features display in the presentation of material with a different perspective from the media in general. The articles are written in relaxed, sarcastic, satirical, and funny.

Founded and funded by Puthut EA, Mojok.co evolved to be an alternative media. He saw an opportunity at that time to build the media, which allow young writers to publish their writings on Mojok.co. It made Mojok.co differ from other media at that time. The unique contents and financial independence become the strength of Mojok.co compared to other online media. As a result, Mojok.co meet the qualification to be alternative media. Downing [1] states that alternative media is often simplified by differentiating it to the mainstream media.

According to Atton [2], alternative media always prioritizes innovation. Mojok.co performs the change on its 
contents: starting from the rubrics, language style and graphic design. The excellence contents are not only exposed from the appearance, but also on how it can get close connection to its viewers' community. Mojok.co has a strong commitment to building engagement with the viewers' community. As an alternative media, Mojok.co in disseminating its contents, has an intention to make a close relationship to its viewers rather than merely conveying information[2].

Puthut EA explained that Mojok.co's expenditure was around 25-30 million rupiahs per month. For three years, the funds spent reached 600 million rupiahs. At the same time the company supporting Mojok.co was going bankrupt, so that it was no longer able to maintain the production cost of Mojok.co. So, Mojok.co had to stop its production due to financial problems. On May 28, 2017, Puthut EA had to announce that Mojok.co was closed widely.

A few months later, on March 28, 2018, Mojok.co reappeared with a new look and more number of rubrics. It was Tirto.id, another online media, to become the investor of Mojok.co. Based on interviews with editors in chief of Tirto.id at the time, Zen RS, the capital injection given to Mojok.co was not motivated by the interest to make a profit. Some media integrations are done for conglomeration to suppress the online media competition so that it could cause more significant profit. Zen RS and Puthut EA had a close relationship since they were students in Yogyakarta. They were in the same connection in the writer's community for years. It became the reason why Tirto.id helped Mojok.co's financial problems so the media can still exist.

However, there are consequences as a result of the integration. First, Mojok.co had to widen its target of viewers. Mojok.co now has targeted to reach more viewers in ages 18-24 years old. Second, Mojok.co's teams are currently working under specific targets. As an effect, the teams of Mojok.co have to work under particular goals. There are no more relaxing work routines because their works are under quite tight targets. Mojok.co has a specific objective to upgrade its performance. The excellent performance is indicated to the ability of the web to be ranked in the top 100 Alexa. When the interview was first conducted (July 2018), Mojok.co was ranked 138, while in March 2018 it was ranked 149. In July 2019 Mojok.co managed to penetrate the top 100 , even able to number 82 .

\section{B. Engagement As The Business Strategy}

In managing online media, engagement becomes very important. Engagement is a measure of online media performance. Engagement means the amount of interaction of each content in the online media. Falls [3] in Social Media Explorer, explains that engagement is communicating well enough that the audience pays attention. Engagement is a communication activity that raises the notice or response of the audience.

Engagement can be interpreted simply as two-way communication. The two-way communication patterns in the study of classical communication explained by Schramm [4] who calls two-way communication interactive, or interactional, that is, communication that takes place circularly, where the communicator sends a message to the communicant, then the communicant responds, then responds again, etc. The key in interactive, interactional, or circular communication is feedback or response to the message because it allows the sender of the message to know the reaction of the message, whether the message sent can be understood or not.

This feedback is underlined by Falls, that in communication, the attention of the public is an indicator of the success of ongoing communication activities. In activities on social media, for example, engagement is measured based on existing interaction features. These features are conversation activities between users, for example through comments and replies; amplification or activity of spreading or expanding messages, such as share, send to and retweet; and applause or short response activities with certain icons, such as likes.

In online media, feedback as an indicator of engagement is not always a conversation. Attention can be expressed through amplification or applause. Even a click can mean attention. Falls [3] asserts, "communication engages those who see the information and pause to click or print". Engagement also occurs even if a passive user only sees, reads, studies, and fills their minds with information conveyed by the media, even if only for an instant, and then they leave the web.

Falls [3] concluded that "to engage an audience is to hold their attention." So, attention is the key to engagement or an indicator of the performance on online media. As a result, online media producers will meet this indicator. There so many webs provide web performance ranking, or web ranking, for example, Alexa or Comscore. The ranking is measured based on the page view or "arrival" of users to a particular website. A page view is the lowest level of engagement. Many page views describe the traffic (web visitors) that occur in the media/web. This traffic then becomes the "god" for the media/web. Therefore, the media will do everything they can to get substantial traffic.

Building strong engagement becomes Mojok.co's goal. As explained in the results of previous studies, the presence of Mojok.co can reach 400,000 views in one day. In one month can reach $4,000,000$ page views. At the time of the interview, Mojok.co was ranked 138 (July 2018), while in March 2018 it was ranked 149. In July 2019 Mojok.co managed to penetrate the top 100, even able to reach number 82. Puthut EA then celebrated this achievement in the article published on June 26, 2019, entitled "Cara Kru Mojok Merayakan Masuk Ranking Alexa 100 Besar (How the Mojok Crew Celebrates Entry to the Top 100 Alexa Ranking)".

Puthut EA was very proud of this achievement, considering that Mojok.co is not a big media with a large budget. This success made Mojok.co able to align itself with the major media, which had already been in the top 100 Alexa ranks.

Alexa is a company that provides financial data related to web traffic. The company is a subsidiary of Amazon.com and was founded in 1996. Alexa created a special toolbar that can collect internet users' surfing habits data. Then this toolbar sends it to the Alexa data centre. These data are stored, then analyzed, and then become the basis of web traffic reports provided by the company to its customers. Web traffic data will serve to facilitate customers to find 
information about web rankings based on the amount of traffic or visitors who enter the web. Alexa ranking is based on historical aggregate traffic for three months from millions of Alexa toolbar users, which is a combination of a page view and reach.

To get a higher rating, Mojok.co must have a high engagement rate. There are two strategies/business models undertaken by Mojok.co, namely content creation and community engagement. Content creation is a type of business that relies on content or content as its main strength. This type of business seeks to build connections with the audience through stories they like. Creative content is a medium for connecting business entities and the audience. Content Creation is a work created by audio, visual, and text through the internet. Content Creation has the potential to become viral because it is unique, inspiring the viewers so that they will like it a lot. Quality content will improve SEO (Search Engine Optimization), which is a technical process to increase the quality of traffic and attract visitors to the web to the fullest. Creative content can be indexed quickly and get higher rankings than low-value content in SEO.

Creative content is an excellent product of Mojok.co. As discussed in previous studies, following the slogan, "Sedikit Nakal Banyak Akal (Little Naughty, Many Sense)", Mojok.co publishes articles written out of the box. The writing style of Mojok.co is a relaxed, humorous writing style, and is similar to a coffee shop chat. Mojok.co often uses satirical language styles that are very different from mainstream media styles.

Community engagement is a business strategy that takes advantage of the community of viewers. Community involvement, according to Lommerse [5] is the process of working with the community to overcome a better life, crossing the boundaries of scientific disciplines and utilizing knowledge. Community involvement has a critical role in online business because community involvement can increase brand awareness. A community can be a strategy of a marketing channel that has a higher involvement value when compared to other marketing channels. Well-managed communities can develop a viral brand in other communities.

Community involvement can be a source of information about trends that occur and develop. Besides, community involvement can also be a source of feedback for the producers. As a result, community involvement is often used to attract sponsors through community activities conducted online and offline.

Mojok.co has an effort to establish closeness with the community, which means that Mojok.co prioritizes community engagement. For that purpose, Mojok.co creates a program to strengthen the community known as a jamboree. This activity is an offline activity that brings together the editorial team of Mojok.co with its loyal readers.

Another strategy is to bring the viewers to get a close connection to famous writers of Mojok.co. Popular writers like Puthut EA, Agus Mulyadi, and Iqbal Daryono are examples of Mojok.co's outstanding writers. They have accounts on social media, such as Facebook or Twitter, which have quite a large number of followers. Their posts on social media described them as part of the Mojok.co team.
These figures can be a representation of Mojok.co in establishing closeness with the viewer.

Mojok.co understands very well that in delivering its content, a media has not only sharing the information. But it is more important to establish specific relationships with readers. It is the intention of engagement, building the bond between the media and its viewers. The increasing view becomes the focus of Mojok.co's business strategies: creative contents and community engagement, which has goals to get high engagement. The success of Mojok.co through the top 100 Alexa rankings is proof of Mojok.co's success in managing engagement.

\section{Managing Engagement, Commodifying Prosumer}

A business model that emphasizes engagement is an implementation of the concept of the commodification of the audience. The concept is based on the idea of assuming users as a source of tradable assets. The audience's attention and actions are engagement. Both are assets, and Mojok.co uses them as commodities to maintain its existence, to its investors and sponsors; and also viewers. It is the practice of audience commodification.

The concept of the commodification of the audience comes from the theory of the political economy of communication. According to Smythe [6], media content will be the lure of recruiting potential audience and maintaining their attention. He introduced the idea of commodity audience to analyze media advertising models. In this model, the audience is sold as commodities to advertisers. The primary function of the media is to prepare the audience to become obedient consumers.

Smythe [6] applies Marx's ideas about the media as a communication tool. According to Smythe, advertisers buy public attention. As a commodity, the producers and buyers (advertisers) manage the audience in the market. In principle, the media industry is based on the audience as the commodity sold to the advertisers [7].

Viewers are audiences, although actually, the concept of audience is not entirely right to describe the characteristics of the viewers. The audience is the passive consumption target, while viewers are not. As a result, this concept is adapted to the study of contemporary business models, for example, in Google's case.

Google treats users as commodities for advertising. Kang and McAllister [8] argue that Google generates profits from advertising by accommodating its broad and transformative users, and through its unique features as spaces for advertising. Comparing to traditional media, Google has commodified its users more intensively. Google's success in maximizing profits has driven innovation in business development [9].

Many researchers argue that commodification is used as a tool to produce value. They said that new technology increases the power of media and business giants to accommodate the audience and sell it to advertisers. However, since the audience in this contemporary business model has more dynamic characteristics both as producers and consumers, Manzerolle [10] proposed the terminology "commodification of prosumer" to explain users participation in this process as well. 
Quoting from Fuchs [11], he said that Alvin Toffler introduced the concept of the prosumer. This concept blurs the boundaries between producers and consumers. In the era of user-generated content and free access on various platforms, the term "user" does not only describe the media consumer, but also the content producer. According to Fuchs [11]], there is user-generated content; the users engage in permanent creative activity, communication, community building, and content production. Users can upload photos, post comments, find information via Google, and so on, which makes the viewers as commodities.

Hearn [12] also described the practice of users commodification in various digital works. By using new technology, users engage in user-friendly digital activities. But, at the same time, the corporations used them more efficiently for their business interest. In one hand, the prosumer becomes the more empowered audience who has roles both consumer and producer. But then, they provide themselves with the valuable assets of the owner of digital modes of production. Jennes [13] also explained the same problem. He rejected the negative impression of the commodification of the audience by introducing the concept of audience empowerment and argued that digital technology could also allow users to control their environment. However, instead of empowering the audience, the media has potentially used the audience.

The practice of prosumer commodification also applies to Mojok.co's production process. Mojok.co utilizes viewers' roles, both as consumers and content providers. To invite viewers to visit the Mojok.co's website, the Mojok.co team created accounts on social media, namely the @mojokdotco on Instagram and Twitter, and @ mojok on Facebook. Based on interviews I did to Puthut EA and Zen RS, it is challenging to expect viewers to visit the web or application directly. The viewers visit the page after someone shared the link of Mojok.co's article on social media. Motivated by this reason, Mojok.co uses the share links from their follower or friend lists on social media to create the viewers' web visit.

As a consequence, creative content has an important role. Creative contents posted in social media will trigger the viewers to push the like button, comment, and even share the articles. Through creative content, Mojok.co can control its viewers to increase engagement so that it will add the number of page views of the web. The increase in the web's page views will raise Alexa's ranking. The higher Alexa's rank shows the improved performance of Mojok.co as the "demands" of Tirto.id's, the investor, and also other sponsors.

In conventional media practice, the audience is sold as a commodity to advertisers. In this process, the audience has "worked" unpaid, and instead, the audience receives media content, including advertisements. The audience eventually becomes the target of advertising. Smythe[5] had already mentioned this kind of practice when he said, "because audience power is produced, sold, purchased and consumed, it commands a price and is a commodity."

Mojok.co makes the viewers as valuable assets. Therefore, Mojok.co manages strong relationships with viewers through community engagement strategies. Technologically, Mojok.co indeed makes its products helpful for the viewers. Mojok.co provides free access to all
Mojok.co's contents. Besides, the viewer is also able to interact with the content providers and other viewers through the conversation tool facilitated by Mojok.co through various social media platforms.

However, the ease of this technology brings the consequences; Fuchs [11] called its implications as the capitalist relations of production. In providing its services, Mojok.co has to exploit its viewers. Viewers are used to increasing page views to the Mojok.co's web through shares, clicks, and comments on various Mojok.co articles. This is the "work" of the viewers to show Mojok.co's performance. The engagement occurred is an implementation of the viewers "work". The result obtained by Mojok.co is the increase of Alexa ranking. This achievement implicates for some profits of Mojok.co. It is not a direct profit, but an injection of funds by investors, in this case, Tirto.id and other sponsors. The profit of Mojok.co is not gained through advertising, because up to now Mojok.co has not advertised.

Quoting Fuchs [11] again, at the level of the technological, productive forces, Mojok.co advances socialization, the co-operative and familiar character of the online-productive forces, Mojok.co are available for free, and give benefit for viewers. But, at the level of the relations of productions, Mojok.co is a profit-oriented which makes use of the viewers to achieve its target in Alexa ranking, to make a profit.

\section{CONCLUSION}

Based on the previous presentation, the outcome is that the community engagement strategy becomes the practice of prosumer commodification. Viewers who act as producers and consumers are also assumed as assets used by Mojok.co to make a profit. The profit referred to in this paper is Mojok.co's ability to improve and maintain its performance.

Some writings on the practice of commodification of prosumer based on research in giant corporations like Google, or Facebook, show the dark side of this practice that exploits users, so they lose their privacy [11][14]. But in Mojok.co's case, the effect of this practice is not that bad. As an alternative media, Mojok.co up to now still has a strong commitment to become a different media that does not merely pursue financial benefits. The decision-maker of Mojok.co and Tirto.id as investors, Puthut EA and Zen RS, both have backgrounds as literacy activists. Based on the results of my research, they now still have a strong commitment to maintaining their idealism.

Pursuing Alexa ranking is Mojok.co's obsession. However, the goal is not to attract advertisers. Achieving Alexa's high ranking has become Mojok.co's ambition, which means Mojok.co, has succeeded in making its site to have a good reputation and performance, equal to big profitoriented media. But after all, Mojok.co is a part of the media industry that requires profit to continue to exist and survive. For this purpose, the viewers become a valuable asset to commodify. Therefore, it is the practice of commodification.

\section{ACKNOWLEDGMENT}

I would like to pay my special regards LP3M UMY for allowing me to finish this research. 


\section{REFERENCES}

[1] J. Downing, Radical Media: Rebellious Communication and Social Movements. 2455 Teller Road, Thousand Oaks California 91320 United States: SAGE Publications, Inc., 2001.

[2] C. Atton, Alternative Media. 1 Oliver's Yard, 55 City Road, London EC1Y 1SP United Kingdom: SAGE Publications Ltd, 2002.

[3] J. Falls, "Defining Engagemen," Social Media Explorer, 2012. [Online]. Available: https://socialmediaexplorer.com/content-sections/news-andnoise/defining-engagement/.

[4] W. Schramm, The process and effects of mass communication. Urbanna: Illinois Press, 1954.

[5] S. Dianne, "Navigating Community Engagement," in M2 Models and Methodologies for Community Engagement, T. Reena, L. Marina, and D. Smith, Eds. Springer US, 2014, pp. 1-21.

[6] D. W. Smythe, "Communications: Blindspot of Western Marxism," Can. J. Polit. Soc. Theory/Revue Can. théorie Polit. Soc., vol. 1, no. 3, pp. 1 27, 1977.

[7] A. Arvidsson and T. Bonini, "Valuing audience passions: From Smythe to Tarde," Eur. J. Cult. Stud., vol. 18, no. 2, pp. 158-173, Apr. 2015, doi: $10.1177 / 1367549414563297$.

[8] H. Kang and M. P. McAllister, "Selling You and Your Clicks Examining the Audience Commodification of Google," tripleC Commun. Capital. Crit. Open Access J. a Glob. Sustain. Inf. Soc., vol. 9, no. 2, pp. 141-153, Jun. 2011, doi: 10.31269/triplec.v9i2.255.

[9] A. Osterwalder and Y. Pigneur, Business Model Generation: A Handbook for Visionaries, Game Changers, and Challengers. New Jersey: Wiley, 2010

[10] V. Manzerolle, "Mobilizing the Audience Commodity: Digital Labour in a Wireless World," in Ephemera: Theory \& Politics in Organization, 2010, pp. 455-469.

[11]C. Fuchs, "Google Capitalism," tripleC Commun. Capital. Crit. Open Access J. a Glob. Sustain. Inf. Soc., vol. 10, no. 1, pp. 42-48, Jan. 2012 , doi: 10.31269/triplec.v10i1.304.

[12]A. Hearn, “Meat, Mask, Burden ', J. Consum. Cult., vol. 8, no. 2, pp. 197-217, Jul. 2008, doi: 10.1177/1469540508090086

[13]D. Khajeheian, "Audience Commodification: A Source of Innovation in Business Models," Technol. Innov. Manag. Rev., vol. 6, no. 8, pp. 40-47, Aug. 2016, doi: 10.22215/timreview/1010.

[14]C. Fuchs, "Web 2.0, Prosumption, and Surveillance," Surveill. Soc., vol. 8, no. 3, pp. 288-309, Sep. 2010, doi: 10.24908/ss.v8i3.4165. 